\title{
Administrative transformation and managerial growth: a longitudinal analysis of changes in the non-academic workforce at Australian universities
}

\author{
Gwilym Croucher $^{1} \cdot$ Peter Woelert ${ }^{2}$
}

Accepted: 31 August 2021 / Published online: 11 September 2021

(C) The Author(s) 2021

\begin{abstract}
One fundamental aspect of organizational transformation in higher education is the change to the profile of universities' non-academic workforce. Key staffing trends identified in recent studies conducted in a variety of national settings include an increase in the proportion of non-academic staff at universities and a shift toward more highly qualified and remunerated non-academic roles. This paper examines the extent to which these trends have played out at Australian universities over the period 1997 to 2017. Drawing on unpublished sets of staffing data, the analyses show that while the proportion of non-academic positions at Australian universities has remained largely stable, there has been a striking and uniform growth in management-rank positions, concurrent with a substantial decline in lower-level and less expensive support roles. This has some significant implications, in particular the growth in more complex "corporate" structures, the relatively fewer staff to support academic work, and the increase in the relative costs associated with maintaining the non-academic workforce at Australian universities.
\end{abstract}

Keywords Non-academic professionals, University management, Administration, Organizational change, Staffing composition, Bureaucratization

Peter Woelert

pwoelert@unimelb.edu.au

Gwilym Croucher

gscrou@unimelb.edu.au

1 Melbourne Centre for the Study of Higher Education, The University of Melbourne, Victoria 3010, Australia

2 Melbourne Graduate School of Education, The University of Melbourne, Victoria 3010, Australia 


\section{Introduction}

Change to the staffing profiles of universities is one fundamental aspect of broader organizational transformation in higher education. Staffing numbers constitute a partial yet concrete indicator of longitudinal organizational shifts within universities, provided that high-quality and sufficiently granular datasets are available for analysis. Their examination facilitates inferences about how universities as formal organizations have responded to evolving policy and funding settings (Baltaru and Soysal 2018; Croucher and Woelert 2016; Stage and Aagaard 2019; Woelert and Croucher 2018). At the same time, staffing makeup provides a window into change in universities' internal power relations, as reflected, for example, in shifting priorities in internal resource allocation.

Many existing studies into changes in universities' staffing profiles share a concern with at least two major trends concerning universities' non-academic staff, or administrative or professional staff, as they are sometimes denoted. First, there is the growth in the proportion of non-academic staff working at universities, relative to the proportion of academic staff or faculty, evident in some countries (Gornitzka et al. 1998; Gumport and Pusser 1995; Rhoades and Sporn 2002). Second there is the increase in highly qualified and remunerated senior-level non-academic positions at universities, concurrent with a decline in lower-level and less expensive non-academic roles (Gornitzka and Larsen 2004; Krücken et al. 2013; Rhoades and Sporn 2002; Stage and Aagaard 2019). Both these trends are of particular interest in that they indicate universities' administration, for better or worse, has become larger and 'topheavier" over recent decades (see Bleiklie et al. 2015; Krücken et al. 2013).

This study seeks to add to the existing body of research on the transformation of the nonacademic workforce at universities through scrutinizing changes in Australian universities' staffing profiles over the period 1997 to 2017. To examine the two above trends identified in many countries, this paper focuses on tracking, first, the proportion of non-academic staff working at Australian universities and, second, the internal composition of the non-academic workforce over the reference period. In doing so, it offers the first in-depth analysis of longterm changes pertaining to the non-academic workforce at Australian universities, drawing on sets of staffing data that are usually not available in the public domain.

In presenting a detailed account of long-term changes in the internal composition of nonacademic staff working at Australian universities, this paper responds to the continuing need for fine-grained national-level analyses of university staffing trends noted in the recent literature (e.g., Baltaru and Soysal 2018; Stage and Aagaard 2019). Australia is widely known for the early and enduring influence New Public Management (NPM) reforms have had on universities as organizations (see the section "New Public Management and university governance in Australia"). As such, the analyses presented in this paper complement recent studies of staffing trends in European higher education systems that were relative latecomers to NPM reforms (e.g., Gornitzka and Larsen 2004; Stage and Aagaard 2019; Krücken et al. 2013) as well as inviting comparison with other early NPM adopters such as UK universities whose staffing dynamics have received attention in the literature (e.g., Whitchurch 2013).

\section{Administrative and organizational change within universities}

Over recent decades, a range of national policy reforms have aimed to create governance conditions that require universities to become strategically acting organizations and which can 
be held accountable for their organizational performance (Bleiklie and Kogan 2007; Paradeise et al. 2009; Ramirez 2006). It is frequently argued that universities have resorted to several organizational responses to cope with these changes in external conditions and expectations.

One typical response has been universities' attempts to strengthen their institutional leadership and management capacities at various organizational levels (Bleiklie and Kogan 2007; Musselin 2007; Thoenig and Paradeise 2016). Of particular note in this regard is the strengthening of universities' central executive, which has in many instances seen significant expansion of its formal authority over core strategic and operational matters (Bleiklie and Kogan 2007; Gumport 2000; Thoenig and Paradeise 2016). Related to this, many universities also have established organization-wide performance monitoring systems, which are used both for internal management purposes and for meeting increased government reporting requirements (see Woelert and McKenzie 2018). Finally, there are indications that, over more recent times, universities around the world have increasingly sought to formalize their internal processes (Ramirez and Christensen 2012; Whitley 2011). Increased formalization is well documented, for example, for key strategic areas such as universities' internal resource allocation mechanisms as well as their external engagement and revenue-seeking activities (Bleiklie et al. 2015; Ramirez and Christensen 2012).

There is much to suggest that the broader changes to macro- and meso-level structures and conditions outlined here have direct implications for the size and configuration of universities' non-academic workforce. This applies first to the growth in the proportion of non-academic staff at universities. While there remain only few systematic attempts at cross-country comparison of university staffing trends using comparable indicators (see Stage 2020), there are indications that such growth has occurred in some national university systems at least over recent decades. Drawing on national datasets, Rhoades and Sporn (2002) showed, for example, that the proportion of non-academic staff across the entire US university system rose from 30.7 to $39 \%$ over the period 1976 to 1995 . For Norwegian universities, it was found that administrative positions grew at a faster rate $(58 \%)$ than their academic counterparts (growth rate of 48\%) over the years 1987 to 1995 (Gornitzka et al. 1998). For Italian universities, nonacademic staff have been reported to have increased by $72.5 \%$ over the years 1991 to 2001 , while academic staff have decreased by around $10 \%$ over the same period (Coccia 2009). By contrast, at Danish or German universities, the proportion of non-academic staff has been shown to have declined over more recent times, partially because of a significant rise in fixedterm academic positions (Krücken et al. 2013; Stage and Aagaard 2019).

Several potential explanations for the growth in universities' non-academic workforce evident in some settings have been put forward over the years. On the one hand, the growth in non-academic staff has been commonly framed as a direct organizational response to changing structural pressures and demands on universities resulting in the main from NPM policies aiming to instill greater efficiency into universities' operations. These changes include, for example, universities' increased external accountability and reporting requirements, as well as a more competitive and diverse funding landscape, both creating a demand for additional administrative positions within universities (Gornitzka et al. 1998). On the other hand, and drawing on the conceptual resources of sociological neo-institutionalism, scholars have stressed that universities' organizational responses often reflect their ambition to maintain or gain external legitimacy by adopting specific organizational forms and practices rather than any immediate structural pressures (e.g., Baltaru and Soysal 2018; Krücken et al. 2013). For example, universities may engage in a range of staffing-intensive organizational activities, such as technology transfer, primarily to satisfy external expectations (Krücken 2014). For the 
same reason, universities may also see increasing formalization as key to managing their increasingly complex relationships with their external environment, something that also creates additional staffing requirements (Baltaru and Soysal 2018; Ramirez and Christensen 2012).

Both structural and institutional forces also have been invoked to explain the shift toward a more highly qualified and highly paid non-academic workforce evident at universities in a diverse range of countries, including the USA (Rhoades and Sporn 2002), Norway (Gornitzka et al. 1998; Gornitzka and Larsen 2004), Germany (Krücken et al. 2013), and Denmark (Stage and Aagaard 2019). Regardless of whether primarily driven by structural needs or legitimacy concerns, the expansion of universities' portfolios in areas such as marketing, equal opportunity, or technology transfer requires the addition of staff possessing specialized skills and experiences and who in many instances need to be hired from the private sector. Professionalization of research management has been singled out as another driver for the growth of highly skilled management professionals at universities (see Gornitzka and Larsen 2004). Finally, and perhaps most importantly, there is the proliferation in various systems of managerial accountability and control established within universities over recent decades and that require dedicated management professionals at various organizational levels (Bleiklie et al. 2015).

Alongside discussion of potential drivers, there is ongoing debate whether the proliferation of more highly qualified and specialized non-academic positions at universities indicates the emergence of a new and distinctive professional group of university managers and administrators (see Schneijderberg and Merkator 2013). Some scholars take the view that the specialization of administrative functions at the university and the transition toward a more managerial modus operandi have given rise to a new class of non-academic professionals at universities (Whitchurch 2013). Relatedly, there is also evidence suggesting that, in some settings at least, a new class of "third space professionals" has emerged whose roles are boundary spanning and not easily located within traditional academic and non-academic structures and cultures (Whitchurch 2013). Yet others have been more hesitant, arguing that while there have been professionalization tendencies among various specialized groups of nonacademic staff, these have not yet resulted in the emergence of one distinct professional group of highly qualified non-academic staff more broadly, and that in many university systems, third-space professionals remain the exception rather than the norm (Gornitzka and Larsen 2004; Krücken et al. 2013).

\section{New Public Management and university governance in Australia}

In Australia and elsewhere, NPM reforms to the governance of universities were in the main motivated by the political ambition to increase both the efficiency and accountability of public universities so that they effectively deliver "value for money."

As an ideal type, NPM governance arrangements for universities are characterized by a strong emphasis on competition and high levels of managerial governance and stakeholder guidance, yet lower levels of both state regulation and academic self-governance (de Boer et al. 2007). It has been well established that ever since a radical NPM-inspired set of higher education policy reforms in the late 1980 s, Australian universities have significantly strengthened managerial self-governance internally, while academic self-governance has been weakened (Rowlands 2017). The same reforms also heralded a fundamental shift from overt state regulation to more indirect yet increasingly comprehensive modes of steering of universities' 
activities through a web of stakeholder guidance mechanisms involving a wide range of targets and standards (see Vidovich and Currie 2011).

The reforms also have strengthened competition between universities at various levels. This is perhaps most strikingly reflected in changes to Australian universities' funding settings. The stagnation in per student public funding from around $90 \%$ in the late 1980s to near half in 2018 showing in Department of Education, Skills and Employment (DESE) figures (n.d.-a) has led universities to vigorously compete for fee-paying international students, for example. Partially as a result of funding changes, Australian universities also came to pursue a strategy of radical expansion more broadly — over the period investigated in this paper (1997 to 2017), overall student enrollments at universities more than doubled, from around 600k to 1.4 million (DESE n.d.-b). In Australia, competition is finally also strongly emphasized in national research funding mechanisms (Woelert and McKenzie 2018), and there is long-standing concern with competition for status or prestige as reflected in various university rankings (see Brankovic 2018).

This paper examines the specific case of Australian universities to examine how long-term changes in non-academic staff cohorts have played out under university governance and funding conditions that in many ways approximate the NPM ideal type.

\section{Data and methods}

To analyze changes in the size and internal composition of non-academic staff, this paper draws on a custom-built dataset enabling a detailed breakdown of staffing numbers (full-time equivalent or FTE) across all relevant categories (e.g., academic vs. non-academic position classifications), ranks (see below), and contract types (full-time or part-time vs casual), for Australian universities over the period 1997 to 2017. ${ }^{1}$ The period of investigation thus covers staffing at all Australian universities over a period of more than 20 years up until recently but excludes the period of radical national policy change in the prior decade due to the unavailability of consistent national data detailing the composition of universities' non-academic staff.

There were 38 and 41 Australian universities operating in 1997 and 2017, respectively, the vast majority of them public. The final analysis covers the majority of these (36 universities for 1997 and 39 for 2017) with only few exceptions. ${ }^{2}$ All reported FTE figures include full-time and aggregated part-time roles (e.g., two 0.5 positions count as one FTE role). The above period includes all years for which granular staffing data were available, combining publicly available data published by DESE (n.d.-c) with additional non-public data sourced from DESE detailing the precise composition of non-academic staff in terms of rank or seniority for each Australian university over the above period.

\footnotetext{
${ }^{1}$ In the Australian context, casual staff are a distinctive group of flexibly used staff who do not have ongoing (or fixed-term) employment or guaranteed hours of work and who are not entitled to provisions such as paid sick and paid annual leave but who technically receive a higher hourly pay rate than their peers working on full-time or part-time contracts. In the Australian economy, casualization is deeply entrenched, across multiple sectors (see Brown et al. 2010).

2 These concern in particular Australia's four non-public universities. For two of these universities established prior to 1997, namely Bond University and University of Notre Dame, staffing data reporting commenced only in the years 2007 and 2000, respectively. In addition to this, the other two more recently established and very small non-public universities - the University of Divinity and Torrens University-were excluded from all analyses, the former because of its status as a specialist institution sharing little similarities with other universities and the latter because analysis of staffing data suggested anomalies.
} 
These sets of data break down ranks (levels of seniority) of university staff in line with the industrial award (Australian Government 2020), which is a standardized national position classification system for the university sector in Australia. For non-academic or, as is the preferred nomenclature in Australia, "professional staff" (see Sebalj et al. 2012), the industrial award uses the "higher education worker" (HEW) classification introduced in the mid-1990s. The HEW classification system comprises ten levels, where HEW 1 marks the lowest and HEW 10 the highest level in terms of required qualifications, level and scope of responsibilities, and remuneration. The award (Australian Government 2020) also stipulates national minimum wages for each HEW level, ranging from AUD41,389.18 (HEW 1) to AUD79,271.60 (HEW 10) in 2020. In practice, however, remuneration of most nonacademic staff is much higher than this. Universities' collective wage agreements suggest that the actual minimum wages paid by universities in the same year tended to be on average around $20 \%$ higher than the legislated minimum wage for HEW 1 positions, for example, and around 50\% higher for HEW 10 positions (National Tertiary Education Union n.d.).

According to the national industrial award classification, HEW levels 1 to 4 mainly include administrative and technical support positions for which no university degree is required. Positions at HEW levels 5 to 7 usually require a university qualification (or equivalent) plus progressively more work experience and may involve, at HEW levels 6 and 7, some direct management and supervision responsibilities. What would typically be understood as genuine management-rank and senior administrative positions start at HEW level 8; from this level upward, a postgraduate qualification (or equivalent) is usually required. Finally, positions at HEW level 10 are explicitly characterized as senior management positions where staff have "substantial management responsibility for diverse activities and/or employees" (Australian Government 2020). The unpublished data on non-academic staff sourced from DESE uses the ten-step HEW classification but also includes two additional categories, one for junior staff such as apprentices and one for senior executive staff who are remunerated, often significantly so, above the HEW 10 award specifications. ${ }^{3}$ Depending on contractual arrangements, academics working in a few selected high-level management roles (notably Pro ViceChancellor or Dean) may be reported against the "senior executive" but not the HEW 10 category (the latter being exclusively used for non-academic staff).

Based upon this formal categorization, and for the purpose of the analyses into changes to the internal composition of non-academic staff, the following four broader analytical staffing categories are used:

(1) The senior executive category is combined with the HEW 10 category to comprise the ranks of senior management staff.

(2) HEW levels 8 and 9 are grouped together to constitute the layer of middle management.

(3) HEW levels 5 to 7 comprise the wide range of degree-qualified regular professionals working, below the management level, in a variety of responsible administrative and technical roles.

(4) HEW levels 1 to 4 comprise those staff working in administrative and technical support roles (support staff).

\footnotetext{
${ }^{3}$ Due to inconsistency in available staffing data these junior staff were not included in the analysis. Staff employed at this level amounted to less than $1 \%$ of all non-academic staff in 2017 . For analysis of shifts in average HEW levels over the years, senior executives are treated as level 11 (one level above HEW 10).
} 
In broad alignment with recent international studies, in this paper we reserve the label "regular professionals" to denote those non-academic staff whose role requires a university qualification (see, e.g., Krücken et al. 2013; Stage \& Aaagaard 2019), but at the same time distinguish these staff from those degree-qualified staff employed in management-rank roles.

Overall, the above categorization facilitates systematic analysis of the changing prevalence of key groups of non-academic staff in terms of seniority, including for both senior and middle management ranks, to a level of detail that goes beyond what has been possible for many other national contexts. At the same time, the same categorization is limiting in not enabling clear insights into the respective share of administrative vs. technical non-academic roles that have been one of the foci of recent research internationally (Stage 2020).

There are some idiosyncrasies to the way Australian universities are asked to report their staffing data to government, and that have implications for the analysis. To begin with, data collection for universities' staff being employed on full-time or part-time contracts are separated from data collection for casual staff who are hired per hour rather than on a set term contract. For the former groups of staff, the census date is 31 March in the reporting year, and staffing data are collected both in terms of headcount and FTE. For the latter group of casual staff, actual rather than estimated figures are generated from the entire calendar year and as an aggregated FTE measure only. At the same time, the actual casual staff data remain less granular than that for full-time and part-time staff in that the latter data provide an exact HEW level breakdown for all non-academic staff, while the actual casual data combine all nonacademic staff into one broad category. As a result, over the period investigated, detailed analyses of shifts within the composition of non-academic staff in terms of specific position ranks and pay levels are possible for full-time and part-time staff only.

The usefulness of staffing figures as an indicator of organizational change depends to a significant extent on consistency of the key staffing categories over time. It is important to note that the very same features also unavoidably imply a certain restriction when it comes to more subtle changes that may not be fully reflected within these categories. One common restriction implicit to national staffing data collection mechanisms (including the one used in Australia) is the binary division into the two mutually exclusive categories of academic and non-academic staff. As indicated, a range of researchers have more recently argued that this division obscures some of the ways in which some of the staff roles found at universities today cut across both academic and non-academic domains (e.g., Whitchurch 2013). Yet despite these boundarycrossing phenomena, most universities around the world continue to formally separate academic and non-academic domains of work. In the case of Australia, this arrangement reflects the fact that the division between academic and non-academic roles remains firmly entrenched in national- or state-level policies and legislation, and is perpetuated by deeply engrained cultural differences in role expectations and occupational value systems between these two groups of staff (Mcinnis 1998; Whitchurch 2013). It is for similar reasons that in recent studies into staffing changes at universities around the world, the division into the categories of nonacademic and academic staff remains a key point of reference (see Baltaru and Soysal 2018; Krücken et al. 2013; Stage 2020; Stage and Aagaard 2019).

To gain insights into how staffing trends have played out at different types of universities, a tripartite typology was employed (see for detailed discussions Croucher and Woelert 2016; Woelert and Croucher 2018). This typology distinguishes the group of the eight most researchintensive Australian universities ("leading research universities", or LRU), which were established before 1960, from those universities established after 1960 but before 1980 ("post 1960 universities"), and from those relatively young universities established after 1980 ("post 
1980 universities"). These three groupings differ significantly in terms of universities' key structural and institutional characteristics. For example, DESE data (DESE n.d.-c) shows that over the period of investigation, the size of staff of the average LRU remained at least double that of the average post 1960 and post 1980 university, suggesting greater organizational complexity also (see Andrews and Boyne 2014). At the same time, in the Australian context, the age of a university generally is a good predictor of its institutional prestige (reinforced by a nationally leading position in pertinent university rankings). ${ }^{4}$ Comparison of staffing patterns across these three groupings is heuristically useful as it can provide insights into the extent to which differences in universities' organizational size and research intensity are also structurally reflected in differences in the size and shape of universities' non-academic workforce. Conversely, striking similarities in staffing patterns across the three groupings may be suggestive of the influence of institutional isomorphic drivers, mimetic (peer-imitation) or otherwise (see Croucher and Woelert 2016).

To analyze changes in the proportion of non-academic staff at Australian universities, the percentage of universities' staff (FTE) working in non-academic roles is tracked over the reference period. Separate analyses are conducted for all staff (including staff on casual contracts, FTE) as well as for those hired on fixed-term or continuing contracts only (FTE). To ensure consistent analysis the non-academic staffing totals used in this context are built from disaggregated staffing figures sourced directly from DESE.

Changes in the internal composition of the non-academic workforce are tracked and analyzed in two ways. First, an index is used to track and depict positive and negative growth dynamics pertaining to the proportion of staff in each of the four major non-academic staffing categories (out of all non-academic staff, FTE) over the reference period. In constructing this index, the proportional size of each of these categories in the year 1997 is used as a baseline. In doing so, this index facilitates comparison of the respective growth dynamics of each staffing category over the entire reference period. Second, to illustrate how these various dynamics pertaining to differently sized groups of staff have ultimately reconfigured the overall composition of the non-academic workforce, the distribution of non-academic staff across the same four categories for the year 1997 (baseline) is compared to that prevailing in the final year of analysis 2017. For further illustration, changes in the distribution of staff across the various HEW classification levels are reported also.

To facilitate comparison of trends and patterns specific to particular types of universities, both of these analyses are conducted for all universities combined and for each of the three university groupings delineated earlier (LRU, post 1960, post 1980).

\section{Findings and discussion}

\section{Changes in the proportion of non-academic staff}

Table 1 shows the size and composition of Australian universities' workforce for each year over the period 1997 to 2017. The figures show that the proportion of non-academic staff of

\footnotetext{
${ }^{4}$ Two outliers are two smaller and less research-focused universities established prior to 1960 and that are located outside the major capital cities - namely the University of New England and the University of Tasmania. These were included in the "post 1960" category rather than the "LRU" category as both share key characteristics with other post 1960 universities except for their date of establishment.
} 
universities' overall workforce (FTE) remained remarkably stable, remaining close to $57 \%$ if excluding and close to $55 \%$ if including casual staff over the entire period. This stability is despite the fact that universities' overall workforce grew by around 50\% (full-time or part-time staff only) or close to $60 \%$ if including casual staff over the reference period.

As Table 2 shows, there also is little difference in the proportion of non-academic staff across the three different university groupings over the reference period, particularly if including casual staff (FTE). Variation between university groupings is slightly larger if considering full-time and part-time staff only. This reflects differences in the extent to which different types of universities rely upon casual staff in their academic and non-academic operations with, for example, the post 1980 universities' academic workforce containing higher proportions of casual staff than that of the LRUs initially, although the figures suggest some slight convergence over the years. Notably, the overall picture of relative similarity in proportion of the non-academic workforce across the various university groupings over the reference period is despite the enduringly high differences in terms of the average size of universities of each grouping - if including casual staff (FTE), in 2017 the LRUs employed on average almost three times as many staff $(6,432)$ as their post 1980 s counterparts $(2,218)$, for example.

\section{Changes to the internal composition of non-academic staff}

In contrast to the stability of the relative size of the non-academic workforce at Australian universities over the years, analysis of the internal composition of non-academic staff revealed

Table 1 Workforce at Australian universities (1997 to 2017)

\begin{tabular}{|c|c|c|c|c|c|c|c|c|}
\hline \multirow[t]{2}{*}{ Year } & \multicolumn{2}{|c|}{$\begin{array}{l}\text { All university staff } \\
\text { (total, FTE) }\end{array}$} & \multicolumn{2}{|c|}{$\begin{array}{l}\text { Non-academic staff } \\
\text { (total, FTE) }\end{array}$} & \multicolumn{2}{|c|}{$\begin{array}{l}\text { Academic staff (total, } \\
\text { FTE) }\end{array}$} & \multicolumn{2}{|c|}{$\begin{array}{l}\text { Proportion of FTE non- } \\
\text { academic staff (of all } \\
\text { staff, in \%) }\end{array}$} \\
\hline & $\begin{array}{l}\text { Excluding } \\
\text { casual staff }\end{array}$ & $\begin{array}{l}\text { Including } \\
\text { casual staff }\end{array}$ & $\begin{array}{l}\text { Excluding } \\
\text { casual staff }\end{array}$ & $\begin{array}{l}\text { Including } \\
\text { casual staff }\end{array}$ & $\begin{array}{l}\text { Excluding } \\
\text { casual staff }\end{array}$ & $\begin{array}{l}\text { Including } \\
\text { casual staff }\end{array}$ & $\begin{array}{l}\text { Excluding } \\
\text { casual staff }\end{array}$ & $\begin{array}{l}\text { Including } \\
\text { casual staff }\end{array}$ \\
\hline 1997 & 69,944 & 80,659 & 39,729 & 44,522 & 30,215 & 36,669 & 56.80 & 55.20 \\
\hline 1998 & 68,958 & 80,084 & 39,179 & 44,020 & 29,779 & 36,454 & 56.82 & 54.97 \\
\hline 1999 & 68,616 & 80,665 & 39,241 & 44,379 & 29,375 & 36,686 & 57.19 & 55.02 \\
\hline 2000 & 68,961 & 81,371 & 39,426 & 44,763 & 29,535 & 37,000 & 57.17 & 55.01 \\
\hline 2001 & 70,020 & 82,674 & 40,089 & 45,473 & 29,931 & 37,702 & 57.25 & 55.00 \\
\hline 2002 & 72,348 & 85,713 & 41,717 & 47,222 & 30,631 & 38,859 & 57.66 & 55.09 \\
\hline 2003 & 74,860 & 88,102 & 43,332 & 48,763 & 31,528 & 39,752 & 57.88 & 55.35 \\
\hline 2004 & 77,533 & 91,074 & 44,870 & 50,289 & 32,663 & 41,179 & 57.87 & 55.22 \\
\hline 2005 & 79,825 & 94,141 & 45,921 & 52,300 & 33,904 & 42,255 & 57.53 & 55.56 \\
\hline 2006 & 81,186 & 95,106 & 46,396 & 52,226 & 34,790 & 43,504 & 57.15 & 54.91 \\
\hline 2007 & 83,289 & 97,425 & 46,927 & 52,574 & 36,362 & 45,082 & 56.34 & 53.96 \\
\hline 2008 & 85,837 & 101,395 & 48,642 & 55,154 & 37,195 & 46,608 & 56.67 & 54.40 \\
\hline 2009 & 90,027 & 106,816 & 51,092 & 57,949 & 38,935 & 48,933 & 56.75 & 54.25 \\
\hline 2010 & 92,297 & 110,160 & 52,490 & 59,702 & 39,807 & 50,792 & 56.87 & 54.20 \\
\hline 2011 & 95,274 & 114,190 & 54,440 & 61,960 & 40,834 & 52,518 & 57.14 & 54.26 \\
\hline 2012 & 98,659 & 117,333 & 56,415 & 64,045 & 42,244 & 53,827 & 57.18 & 54.58 \\
\hline 2013 & 100,292 & 119,687 & 57,402 & 65,449 & 42,890 & 54,586 & 57.23 & 54.68 \\
\hline 2014 & 101,894 & 122,139 & 58,420 & 66,609 & 43,474 & 56,091 & 57.33 & 54.54 \\
\hline 2015 & 102,247 & 123,532 & 58,819 & 67,465 & 43,428 & 56,846 & 57.53 & 54.61 \\
\hline 2016 & 104,008 & 125,601 & 59,638 & 68,121 & 44,370 & 58,115 & 57.34 & 54.24 \\
\hline 2017 & 105,682 & 128,067 & 60,563 & 69,338 & 45,119 & 59,820 & 57.31 & 54.14 \\
\hline
\end{tabular}




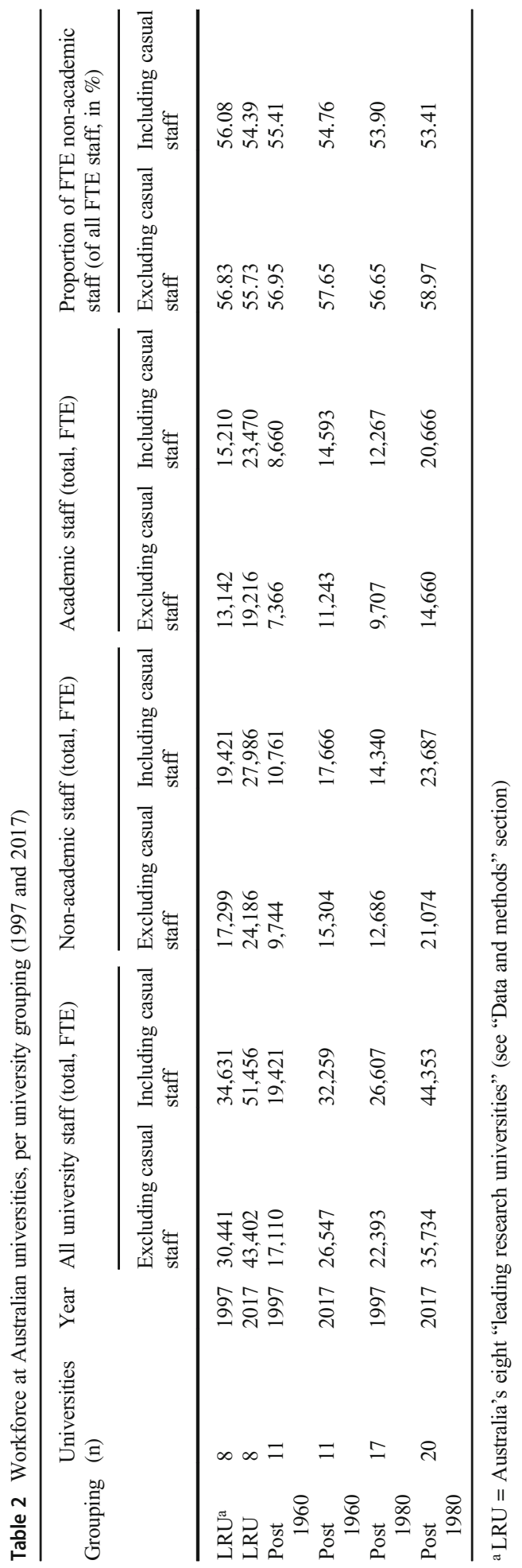


considerable shifts and changes. Figure 1 depicts the growth dynamics, positive and negative, pertaining to the proportional size of each of the four key non-academic staffing categories over the entire reference period of 21 years, using the year 1997 as a baseline $(=100)$.

Key changes played out in relatively uniform fashion across all three university groupings. Out of all non-academic staffing categories and across all universities, the proportion of middle management positions grew at the highest rate (122\%), reflecting an increase in the share of such positions, out of all non-academic roles, from approx. 9.27 to $20.57 \%$ over the reference period (see Figure 2). The growth in the share of middle management roles was the highest at the post 1980 universities (144\%). The proportion of senior management roles increased at a considerable rate also at around $110 \%$ (reflecting an increase in the share of such roles from 3.68 to $7.71 \%$ across all universities). Growth in such positions was most pronounced at the LRUs (127\%). The proportion of regular professional roles also increased over the reference period but at a considerably slower rate (37\%) than senior and middle management roles (reflecting a growth in share from 42.22 to $58.05 \%$ ). In marked contrast to these trends, the proportion of staff employed in support roles declined significantly at around $70 \%$ across all universities (decreasing its share from 44.83 down to $13.68 \%$ ). This decline occurred at a very similar rate for each university grouping, following a strikingly linear trajectory over time.

Figure 2 summarizes the outcome and extent of change to the internal composition of the non-academic workforce that occurred over the entire reference period. As can be seen, across all universities and at each university grouping, the proportion of management-ranked roles (both senior and middle) increased considerably, while the proportion of support staff roles declined significantly. This change is the more striking if considering the absolute change in staffing numbers from 1997 to 2017. Over this period, the number of management-level staff at Australian universities rose from 4,970 to 16,629, effectively an increase by a factor of 3.35 .
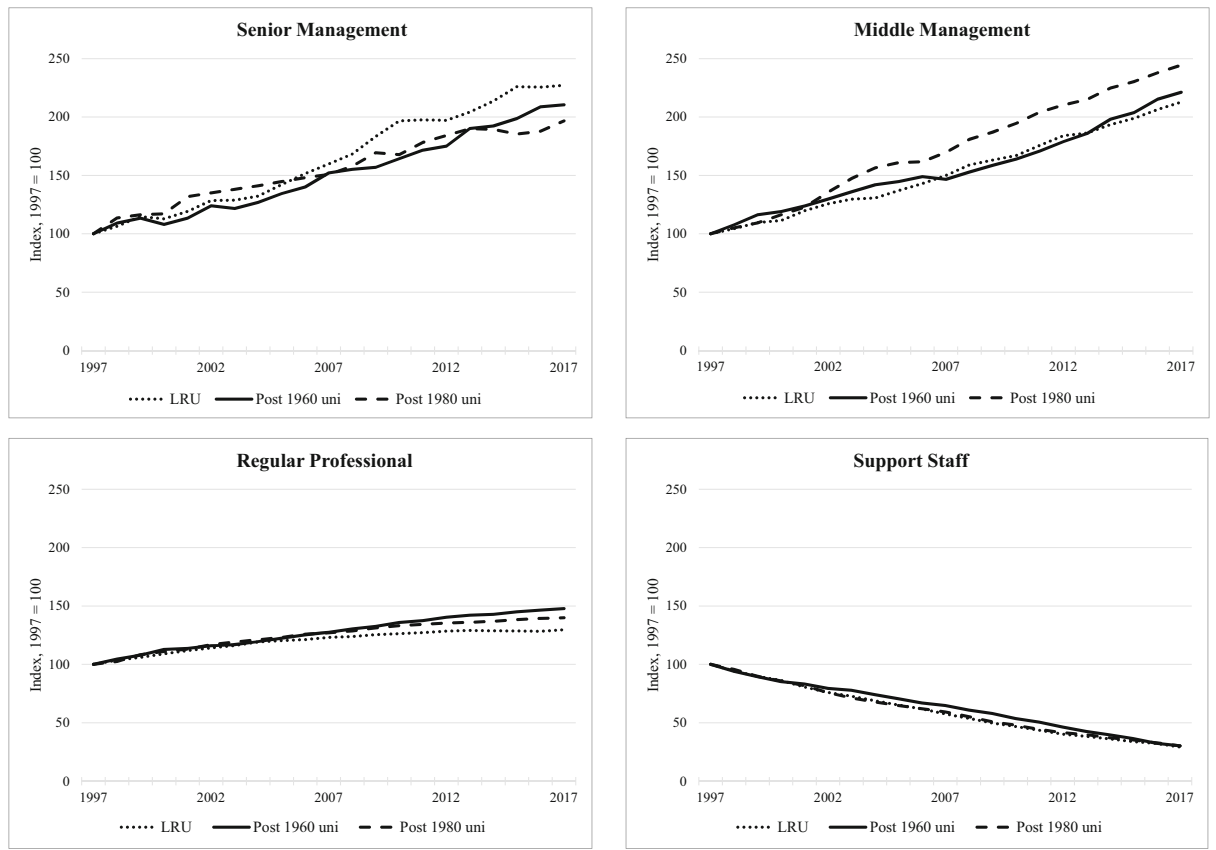

Fig. 1 Index of changes in composition of non-academic staff, 1997 to 2017, by category 

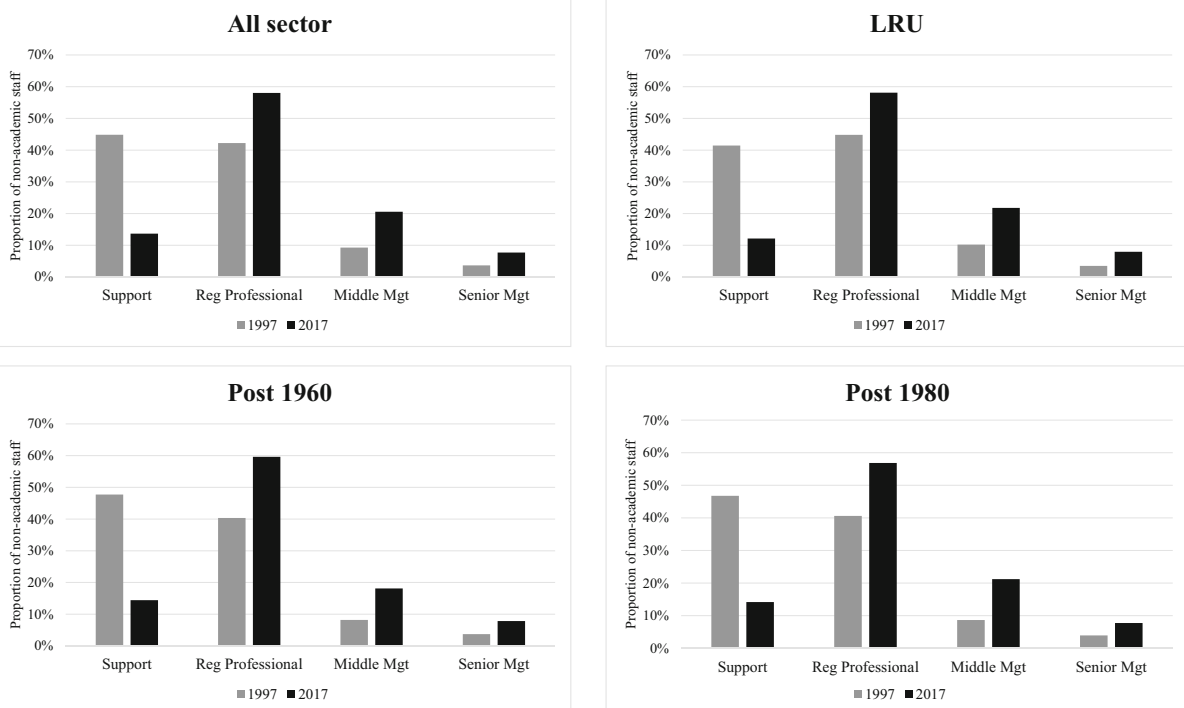

Fig. 2 Composition of non-academic workforce at Australian universities, 1997 and 2017

By contrast, over the same period, the number of support staff roles declined in absolute terms from 17,094 to 7,787 , despite the considerable growth in overall staff numbers at all universities occurring over the years.

The shift toward more highly ranked non-academic positions is also reflected in an increase in the mean HEW level of non-academic roles across all universities, from an average of 5.04 in 1997 to 6.48 in 2017. At the LRUs, the average HEW level increased from 5.14 to 6.56, the post 1960 universities went from a mean HEW of 4.93 to 6.4, and at the post 1980 universities, the HEW average level rose from 5.02 to 6.5 .

\section{Dynamics, drivers, and implications}

This analysis shows that there have been significant changes to the makeup of the nonacademic staff in Australian universities that in important respects correspond with key dynamics observed at universities around the world. While the non-academic workforce at Australian universities has remained remarkably stable in terms of its relative size compared to the academic workforce, over the last two decades, there has been a significant distributional shift from lower level toward more highly ranked (and remunerated) non-academic positions.

To begin with, Australian universities have not seen the increase in the proportion of nonacademic staff that has been reported for highly marketized university systems, such as in the USA (Rhoades and Sporn 2002). At around 55\%, the proportion of non-academic staff at Australian universities also remains well below that of their US counterparts (see Stage 2020). At the same time, this proportion is high compared to countries such as Germany and Denmark where universities receive the bulk of their funding directly from government (see Krücken, Blümel, and Klok 2013; Stage and Aagaard 2019).

The notable increase in more highly paid and ranked non-academic positions alongside a decrease in support roles at Australian universities largely mirrors the patterns of restructuring the non-academic workforce observed elsewhere (Stage 2020). Although in-depth comparison 
of patterns of growth pertaining to specific categories of non-academic staff across university systems remains challenging due to the differences in national staffing datasets, the growth in management-rank positions at Australian universities looks pronounced. What is also striking is how uniform this shift has occurred at a steady pace across very different types of Australian universities. This finding lends support to previous research (Croucher and Woelert 2016; Woelert and Croucher 2018) suggesting that universities in Australia are prone to resorting to isomorphism when changing as organizations (see also below).

The data and analyses reported in this paper cannot provide direct confirmation of underlying drivers and factors. Nonetheless, and considering previous insights into potential drivers behind changes in universities' non-academic workforce around the world (Baltaru and Soysal 2018; Gornitzka et al. 1998; Gumport and Pusser 1995), the key staffing trends and patterns identified suggest that both structural and institutional forces may have played a role.

To begin with, the progressive growth in senior and middle management-level staff is likely to reflect Australian universities' attempts to strengthen their institutional leadership at various organizational levels in response to structural needs created by national NPM policy trajectories emphasizing competition and performance-based accountability. For example, most Australian universities have considerably built up their research management staff and operations over recent decades (see Beerkens 2013) both to meet progressively expanded governmental reporting and compliance requirements and to develop strategies to improve universities' performance in various university rankings. Related to this, there also appears to have been a proliferation of management-level roles that directly reflect changing governmental policy priorities and the associated incentives and pressures. This includes, for example, roles ostensibly dedicated to furthering universities' student equity or research impact missions.

At the same time, a stagnation in per student public funding as well as a shared concern about university rankings have made it imperative for Australian universities to pursue entrepreneurial agendas to diversify and grow their revenue. The coordination of such agendas can be challenging and resource-intensive, and particularly so the larger and more complex universities become (see Andrews and Boyne 2014). As universities evolve to be more entrepreneurial, they add senior and middle management positions with responsibility for newly established portfolios such as marketing or philanthropy. Due to coordination problems associated with organizational complexity and scale, and a firmly entrenched culture of intraorganizational competition for research income or high-quality students, to only mention a few, these positions may then be duplicated multiple times across each university. The same coordination challenges also may constitute an impetus for the addition of compliance-focused middle management and regular professional positions across the university.

Similarly, once universities establish portfolios such as alumni relations or community engagement, these need to be staffed with qualified professionals bringing to the position relevant skills and expertise, thus driving growth among this group of staff. Change to how universities teach and support their students is another likely driver for the growth in regular professional staff. The shift to online education, for example, has given rise to a new class of teaching- or student-focused professional staff at Australian universities (and many of which fit the bill of "third space professionals"). Finally, some of the observed growth among lowerlevel regular professional staff (HEW 5 and 6) may reflect "classification creep" in the form of progressive reclassifications of roles for the purposes of increasing remuneration, although it would be difficult to find evidence to confirm this. Similarly, it is likely that selected, particularly highly qualified or in-demand professionals are employed on middle 
management-rank contracts even though they do not have generic management responsibilities.

Apart from any potential impacts of classification creep, the marked decline in support staff positions over the reference period has likely been driven by two major developments. First, there is the progressive automation of administrative tasks such as record management or data entry previously undertaken manually by support staff. Second, there is universities' increased use of outsourcing, initially in areas such as cleaning services or ground and building maintenance but then potentially also spreading to their student support and IT support functions, for example, which reduces the number of support staff directly employed by universities. Additionally, it cannot be ruled out that some roles associated with support functions have been shifted to the category of professional roles, reflecting a reclassification of roles (see above) as well as professionalization tendencies among non-academic staff more broadly.

The presence of structural pressures on universities leading to organizational change does not preclude the efficacy of institutional forces. To begin with, institutional forces can shape how structural pressures are perceived within a university and, more importantly, what are seen as legitimate ways of responding to these pressures (see Baltaru and Soysal 2018; Krücken 2014). At the same time, staffing patterns across the three university groupings show significant similarity despite the difference in some of universities' key structural characteristics, such as the average size and levels of research intensity, and which imply differently articulated structural needs. It may well be the case, then, that the observed similarity in staffing patterns across structurally different types of universities reflects institutional isomorphic forces such as various forms of organizational mimicking, rather than any immediate structural pressures. A particular, cross-sectoral form of organizational mimicking could also be one driving force behind the observed growth in senior management roles, as is reflected in the proliferation of senior executive positions at universities the titles of which resemble those found in corporate organizations (such as Vice-President Strategy, Chief Marketing Officer, or Executive Director Governance and Risk). However, in-depth empirical research would be needed to confirm these assumptions (see Fay and Zavattaro 2016).

Overall, there are several important implications resulting from the key staffing trends identified which all warrant closer attention in future research. First, despite the overall stability in terms of its relative size, the shift toward more highly ranked and remunerated roles more broadly and the expansion of management-ranked staff more specifically suggests that the relative costs associated with maintaining the non-academic workforce at Australian universities have progressively increased over recent decades. Similar to other recent findings from other university systems, this finding seems to trouble the NPM policy narrative that increases in organizational competition and in managerial and financial autonomy for universities will automatically translate into greater organizational efficiency and effectiveness also.

Second, the striking increase in non-academic management-ranked roles also lends some support to the notion that at Australian universities, the legitimating idea of the university as a specific, academically focused institution has largely given way to the notion of the university being an organization like any other (see Musselin 2007). This shift means that managerial techniques and solutions originating in the corporate sector become seen to be readily applicable to universities also, thus leading to a proliferation of management-focused nonacademic staff roles over time as one key element of a broader "corporate" transformation of academic and non-academic work processes at Australian universities (see Szekeres 2006). 
Third, and related to this, it is important to consider how the key changes in the profile of nonacademic staff identified may impact the conditions for universities' research and teaching operations on the ground. Various commentators have noted that, around the world, academic staff appear to spend increasing amounts of their time on completing administrative paperwork (see Bozeman and Youtie 2020). The Australian system appears to be no different; on the contrary, in a survey conducted in 2008 across 13 countries, Australian professors reported to spend more time on administrative duties than any of their international peers (Bentley and Kyvik 2012). This fact may well reflect, on the one hand, the proportional reduction in support staff positions observed, meaning that many of the administrative duties initially performed by support staff are now automated but handled by academic staff themselves (see Bozeman and Youtie 2020). On other hand, it may directly reflect the strengthening of various managerial reporting systems at universities imposing an increasing administrative burden on academic but also non-academic staff (see Szekeres 2006) for which the steady increase in management-level staff is one key proxy.

\section{Final reflection}

Beyond the broader directions for further enquiry just outlined, there are a number of concrete avenues for future study either complementing or directly extending upon the analyses presented in this paper.

Perhaps most importantly, there remains a pressing need, not only in Australia but internationally, for in-depth analyses providing a better understanding of how changes in universities' non-academic staffing numbers correspond with specific changes in universities' various management portfolios and organizational functions (e.g., marketing or IT). Singleuniversity or small-n case studies that examine selected universities' human resources records detailing job titles and responsibilities for each non-academic position over an extended period of time hold considerable promise in this regard. Such systematic studies of universities' records could be fruitfully combined with interview-based studies examining how universities' leadership explains and rationalizes staffing trends with regard to changes to specific organizational domains and functions.

The analyses presented in this paper also establish a foundation for more targeted inferential analyses into potential factors associated with the key staffing trends identified in this paper. For example, such analyses could be used to examine in detail the extent to which patterns of growth in the relative size of senior management at Australian universities are predicated upon structural organizational changes, such as increases in student numbers. Similarly, inferential analyses could be fruitfully employed to examine the strength of association between changes in the size of key staffing groups at universities and to determine on this basis the respective impact that changes in the size of specific groups of staff have on the size of others.

Finally, and despite some recent progress that has been made in this area, there continues to be a need for detailed and systemic studies comparing changes in the relative size and internal composition of the non-academic workforce at universities across national jurisdictions. In the present case, comparison with national cases that share similarities in terms of macro-level policy trajectories and the associated university governance and funding settings, notably the UK, could be a good starting point. However, to gain better understanding of potential drivers, the inclusion of a number of national cases that reflect much greater heterogeneity in macrolevel settings could be particularly illuminating. 
Acknowledgements We would like to thank Ai Tam Le for research assistance and Vin Massaro, Andrew Norton, James Waghorne and the two anonymous reviewers for their comments and suggestions.

Open Access This article is licensed under a Creative Commons Attribution 4.0 International License, which permits use, sharing, adaptation, distribution and reproduction in any medium or format, as long as you give appropriate credit to the original author(s) and the source, provide a link to the Creative Commons licence, and indicate if changes were made. The images or other third party material in this article are included in the article's Creative Commons licence, unless indicated otherwise in a credit line to the material. If material is not included in the article's Creative Commons licence and your intended use is not permitted by statutory regulation or exceeds the permitted use, you will need to obtain permission directly from the copyright holder. To view a copy of this licence, visit http://creativecommons.org/licenses/by/4.0/.

Open Access This article is licensed under a Creative Commons Attribution 4.0 International License, which permits use, sharing, adaptation, distribution and reproduction in any medium or format, as long as you give appropriate credit to the original author(s) and the source, provide a link to the Creative Commons licence, and indicate if changes were made. The images or other third party material in this article are included in the article's Creative Commons licence, unless indicated otherwise in a credit line to the material. If material is not included in the article's Creative Commons licence and your intended use is not permitted by statutory regulation or exceeds the permitted use, you will need to obtain permission directly from the copyright holder. To view a copy of this licence, visit http://creativecommons.org/licenses/by/4.0/.

\section{References}

Andrews, R., \& Boyne, G. A. (2014). Task complexity, organization size, and administrative intensity: The case of UK universities. Public Administration, 92(3), 656-672.

Australian Government (2020). Higher Education Industry-General Staff-Award 2020. Retrieved July 15, 2020 from: http://awardviewer.fwo.gov.au/award/show/MA000007

Baltaru, R. D., \& Soysal, Y. N. (2018). Administrators in higher education: Organizational expansion in a transforming institution. Higher Education, 76(2), 213-229.

Beerkens, M. (2013). Facts and fads in academic research management: The effect of management practices on research productivity in Australia. Research Policy, 42(9), 1679-1693.

Bentley, P. J., \& Kyvik, S. (2012). Academic work from a comparative perspective: A survey of faculty working time across 13 countries. Higher Education, 63(4), 529-547.

Bleiklie, I., \& Kogan, M. (2007). Organization and governance of universities. Higher Education Policy, 20(4).

Bleiklie, I., Enders, J., \& Lepori, B. (2015). Organizations as penetrated hierarchies: Environmental pressures and control in professional organizations. Organization Studies, 36(7), 873-896.

Bozeman, B., \& Youtie, J. (2020). Robotic bureaucracy: Administrative burden and red tape in university research. Public Administration Review, 80(1), 157-162.

Brankovic, J. (2018). The status games they play: Unpacking the dynamics of organisational status competition in higher education. Higher Education, 75(4).

Brown, T., Goodman, J., \& Yasukawa, K. (2010). Academic casualization in Australia: Class divisions in the university. Journal of Industrial Relations, 52(2), 169-182.

Coccia, M. (2009). Bureaucratization in public research institutions. Minerva, 47(1), 31-50.

Croucher, G., \& Woelert, P. (2016). Institutional isomorphism and the creation of the unified national system of higher education in Australia: An empirical analysis. Higher Education, 71(4), 439-453.

de Boer, H., Enders, J., \& Schimank, U. (2007). On the way towards new public management? The governance of university systems in England, the Netherlands, Austria, and Germany. In D. Jansen (Ed.), New Forms of Governance in Research Organizations (pp. 137-152). Dordrecht: Springer.

DESE (Department of Education, Skills and Employment) (n.d.-a). Finance: Financial Reports of Higher Education Providers. Retrieved from: https://www.education.gov.au/finance-publication.

DESE (Department of Education, Skills and Employment) (n.d.-b). Higher education statistics: Student data. Retrieved from: https://www.education.gov.au/staff-data.

DESE (Department of Education, Skills and Employment) (n.d.-c). Higher education statistics: Staff data. Retrieved from: https://www.education.gov.au/staff-data.

Fay, D. L., \& Zavattaro, S. M. (2016). Branding and isomorphism: The case of higher education. Public Administration Review, 76(5), 805-815. 
Gornitzka, Å., \& Larsen, I. M. (2004). Towards professionalisation? Restructuring of administrative work force in universities. Higher Education, 47(4), 455-471.

Gornitzka, A., Kyvik, S., \& Larsen, I. M. (1998). The bureaucratisation of universities. Minerva, 36(1), 21-47.

Gumport, P. J. (2000). Academic restructuring: Organizational change and institutional imperatives. Higher Education, 39(1), 67-91.

Gumport, P. J., \& Pusser, B. (1995). A case of bureaucratic accretion: Context and consequences. The Journal of Higher Education, 66(5), 493-520.

Krücken, G. (2014). Higher education reforms and unintended consequences: A research agenda. Studies in Higher Education, 39(8), 1439-1450.

Krücken, G., Blümel, A., \& Kloke, K. (2013). The managerial turn in higher education? On the interplay of organizational and occupational change in German academia. Minerva, 51(4), 417-442.

Mcinnis, C. (1998). Academics and professional administrators in Australian universities: Dissolving boundaries and new tensions. Journal of Higher Education Policy and Management, 20(2), 161-173.

Musselin, C. (2007). Are universities specific organizations? In G. Krücken, A. Kosmützky, \& M. Torka (Eds.), Towards a multiversity? Universities between global trends and national traditions (pp. 63-84). Transcript.

National Tertiary Education Union (n.d.). Agreements. Retrieved February 182021 from: https://www.nteu.org. au/rights/agreements/universities

Paradeise, C., Reale, E., Bleiklie, I., \& Ferlie, E. (Eds.). (2009). University governance: Western European comparative perspectives. Springer.

Ramirez, F. O. (2006). The rationalization of universities. In M.-L. Djelic \& K. Sahlin-Andersson (Eds.), Transnational governance: Institutional dynamics of regulation. Cambridge University Press.

Ramirez, F. O., \& Christensen, T. (2012). The formalization of the university: Rules, roots, and routes. Higher Education, 65(6), 695-708.

Rhoades, G., \& Sporn, B. (2002). New models of management and shifting modes and costs of production: Europe and the United States. Tertiary Education and Management, 8(1), 3-28.

Rowlands, J. (2017). Academic governance in the contemporary university: Perspectives from anglophone nations. Springer.

Schneijderberg, C., \& Merkator, N. (2013). The new higher education professionals. In B. M. Kehm \& U. Teichler (Eds.), The academic profession in Europe: New tasks and new challenges (pp. 53-92). Springer.

Sebalj, D., Holbrook, A., \& Bourke, S. (2012). The rise of "professional staff" and demise of the "nonacademic": A study of university staffing nomenclature preferences. Journal of Higher Education Policy and Management, 34(5), 463-472.

Stage, A. K. (2020). Are national university systems becoming more alike? Long-term developments in staff composition across five countries. Policy Reviews in Higher Education, 4(1), 68-104.

Stage, A. K., \& Aagaard, K. (2019). Danish universities under transformation: Developments in staff categories as indicator of organizational change. Higher Education, 78(4), 629-652.

Szekeres, J. (2006). General staff experiences in the corporate university. Journal of Higher Education Policy and Management, 28(2), 133-145.

Thoenig, J. C., \& Paradeise, C. (2016). Strategic capacity and organisational capabilities: A challenge for universities. Minerva, 54(3), 293-324.

Vidovich, L., \& Currie, J. (2011). Governance and trust in higher education. Studies in Higher Education, 36(1), 43-56.

Whitchurch, C. (2013). Reconstructing identities in higher education: The rise of "third space" professionals. Routledge.

Whitley, R. (2011). Changing governance and authority relations in the public sciences. Minerva, 49(4), 359385.

Woelert, P., \& Croucher, G. (2018). The multiple dynamics of isomorphic change: Australian law schools 19871996. Minerva, 56(4), 479-503.

Woelert, P., \& McKenzie, L. (2018). Follow the money? How Australian universities replicate national performance-based funding mechanisms. Research Evaluation, 27(3), 184-195.

Publisher's note Springer Nature remains neutral with regard to jurisdictional claims in published maps and institutional affiliations. 